\title{
Predation on a Cuban Brown Anole, Anolis sagrei (Dactyloidae), by a Spider, Cupiennius cubae (Ctenidae), in the Cienfuegos Botanical Garden, South-central Cuba
}

\author{
Elier Fonseca Hernández ${ }^{1}$ and Tomás M. Rodríguez-Cabrera ${ }^{2}$
}

${ }^{1}$ Departamento de Biología Animal y Humana, Facultad de Biología, Universidad de la Habana, La Habana, CP 10400, Cuba (elierfonseca@fbio.uh.cu) 2Jardín Botánico de Cienfuegos, Cienfuegos, PC 59290, Cuba (tomasmichel.rodriguez@gmail.com)

A rthropods, including arachnids (scorpions, spiders, sun spiders, whip spiders, whip scorpions), insects (water bugs, ants, beetles, dragonfly, caddisfly and stonefly nymphs), crustaceans (crabs, shrimps), and centipedes (Scolopendra spp.), are known predators of small vertebrates (e.g., McCormick and Polis 1982, Menin et al. 2005, Toledo 2005, Henderson and Powell 2009), but spiders are by far the most frequently reported vertebrate predators of anurans and lizards. Wandering Spiders (Ctenidae) are known to prey on amphibians and reptiles in the Neotropics (e.g., Menin et al. 2005, Barbo et al. 2009, Barej et al. 2009, Losos 2009). However, West Indian records are scarce. Ctenus ottleyi (= Oligoctenus ottleyi; Platnick 2009) from Puerto Rico preys on Eleutherodactylus coqui (Falls and Woolbright in Formanowicz et al. 1981, Joglar 2005) and Anolis gundlachi (Clark and Gillingham 1990); and Ohvida vernalis (= Ctenus vernalis; Platnick 2009) from Cuba was observed preying on E. zugi (Novo et al. 1985).

Although the Cuban Brown Anole (Anolis sagrei Cocteau in Duméril and Bibron 1837) is one of the most widely distributed West Indian lizards, it is native to the Bahamas, the Cuban Archipelago, and Little Cayman (Henderson and Powell 2009). A great variety of vertebrates are known predators of this anole in nature, including frogs (Osteopilus), snakes (Caraiba, Cubophis, Tropidophis), lizards (Anolis, Leiocephalus), and birds (Dives, Falco, Ferminia, Quiscalus, Mimus) (for a review see Henderson and Powell 2009, Losos 2009). However, only one report of an arthropod preying on this lizard involved an Orbweaver, Argiope trifasciata (Armas 2001). Herein we report predation on Anolis sagrei by Cupiennius cf. cubae Strand 1909, in south-central Cuba. To the best of our knowledge this constitutes the first record of a ctenid spider preying on lizards in the Cuban Archipelago, and only the second case reported in the West Indies.
On 25 January 2014, at $2250 \mathrm{~h}$, an adult female Cupiennius cf. cubae (8.6 $\mathrm{mm}$ carapace length, $0.94 \mathrm{~g}$ ) was found devouring an immature male $A$. sagrei $(31 \mathrm{~mm}$ SVL, 0.72 g) (Fig. 1). Both animals were on a bromeliad (Tillandsia valenzuelana) $210 \mathrm{~cm}$ above ground level in a tree at the Cienfuegos Botanical Garden $\left(22^{\circ} 07^{\prime} 31.5^{\prime \prime} \mathrm{N}\right.$, $-80^{\circ} 19^{\prime} 20.2^{\prime \prime} \mathrm{W} ; 50 \mathrm{~m}$ a.s.l.), Cienfuegos Province; air tem-
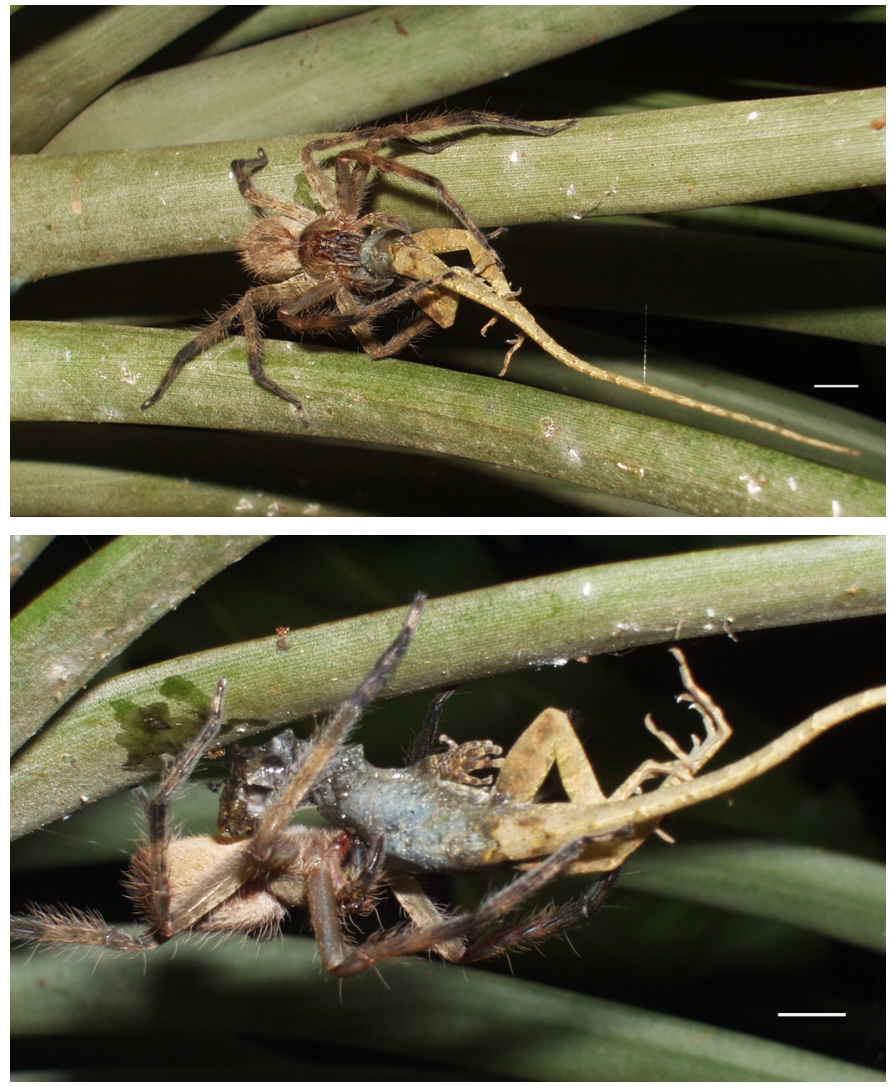

Fig. 1. Predation on Anolis sagrei by Cupiennius cf. cubae in the Cienfuegos Botanical Garden, Cuba. Scale bars $=5 \mathrm{~mm}$. 
perature $21{ }^{\circ} \mathrm{C}$. At the time of the observation, soft tissues of the lizard's head and anterior body were partially digested. The spider was hanging in an inverted position from the leaf of a bromeliad, holding the lizard with the first pair of legs and the chelicera. Another four individuals of $A$. sagrei were sleeping in the same bromeliad and adjacent twigs. After collection, the spider persisted in holding the prey despite considerable disturbance.

The spider was tentatively referred to Cupiennius cubae because this is the only species of this genus known to occur in Cuba. Both spider and lizard were deposited in the herpetological collection of the Museo de Historia Natural "Felipe Poey," Faculty of Biology, University of Havana (MFP 12516).

\section{Acknowledgements}

We thank Ansel Fong, Javier Torres, and Ruben Marrero for help with the literature. J. Torres also made useful comments that improved the manuscript.

\section{Literature Cited}

Armas, L.F. de. 2001. Frogs and lizards as prey of some Greater Antillean arachnids. Revista Ibérica de Aracnología 3:87-88.

Barej, M.F., J.A.M. Wurstner, and W. Böhme. 2009. Predation on the treefrog Leptopelis brevirostris (Anura: Arthroleptidae) by a Wandering Spider
(Araneae: Ctenidae) in Cameroon. Herpetology Notes 2:137-139.

Barbo, F.E., M.G. Rodrigues, F.M. Couto, and R.J. Sawaya. 2009. Predation on Leptodactylus marmoratus (Anura: Leptodactylidae) by the spider Ctenus medius (Araneae: Ctenidae) in the Atlantic Forest, southeast Brazil. Herpetology Notes 2:99-100.

Clark, D.L. and J.C. Gillingham. 1990. Sleep-site fidelity in two Puerto Rican lizards. Animal Behavior 39:1138-1148.

Formanowicz, D.R., Jr., M.M. Steward, F.H. Pough, and P.F. Brussard. 1981. Predation by Giant Crab Spiders on the Puerto Rican frog Eleutherodactylus coqui. Herpetologica 37:125-129.

Henderson, R.W. and R. Powell. 2009. Natural History of West Indian Reptiles and Amphibians. University Press of Florida, Gainesville.

Joglar, R.L. 2005. Anfibios, pp. 39-96. In: R.L. Joglar (ed.), Biodiversidad de Puerto Rico. Vertebrados Terrestres y Ecosistemas. Serie de Historia Natural. Editorial Instituto de Cultura Puertorriqueña, San Juan.

Losos, J.B. 2009. Lizards in an Evolutionary Tree. Ecology and Adaptive Radiation of Anoles. University of California Press, Berkeley and Los Angeles.

McCormick, S. and G.A. Polis. 1982. Arthropods that prey on vertebrates. Biological Review 57:29-58.

Menin, M., D. de Jesus Rodrigues, and C.S. de Azevedo. 2005. Predation on amphibians by spiders (Arachnida, Araneae) in the Neotropical region. Phyllomedusa 4:39-47.

Novo Rodríguez, J., A.R. Estrada, and G. Alayón. 1985. Eleutherodactylus (Anura: Leptodactylidae) depredado por un aranéido. Miscelánea Zoológica 28:1-2.

Platnick, N.I. 2009. The World Spider Catalog, Version 10.0. The American Museum of Natural History (http://research.amnh.org/entomology/spiders/ catalog/index.html).

Toledo, L.F. 2005. Predation of juvenile and adult anurans by invertebrates: Current knowledge and perspectives. Herpetological Review 36:395-400. 